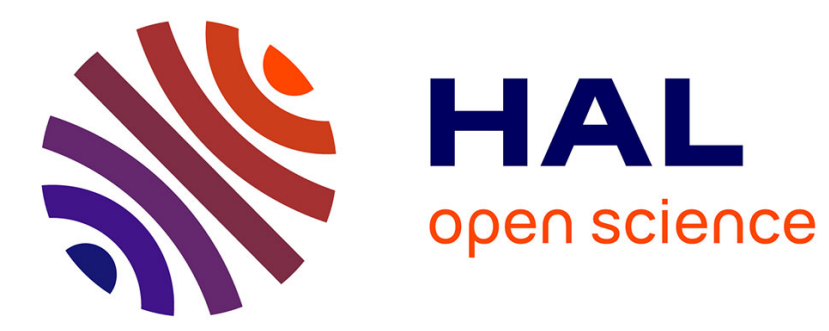

\title{
Thermodynamic Analysis of the Chemical Vapor Deposition of Phosphorus Nitride (P3N5) Thin Films
}

\author{
S. Eroglu
}

\section{To cite this version:}

S. Eroglu. Thermodynamic Analysis of the Chemical Vapor Deposition of Phosphorus Nitride (P3N5) Thin Films. Journal de Physique IV Proceedings, 1995, 05 (C5), pp.C5-79-C5-86. 10.1051/jphyscol:1995506 . jpa-00253762

HAL Id: jpa-00253762

https://hal.science/jpa-00253762

Submitted on 1 Jan 1995

HAL is a multi-disciplinary open access archive for the deposit and dissemination of scientific research documents, whether they are published or not. The documents may come from teaching and research institutions in France or abroad, or from public or private research centers.
L'archive ouverte pluridisciplinaire HAL, est destinée au dépôt et à la diffusion de documents scientifiques de niveau recherche, publiés ou non, émanant des établissements d'enseignement et de recherche français ou étrangers, des laboratoires publics ou privés. 


\title{
Thermodynamic Analysis of the Chemical Vapor Deposition of Phosphorus Nitride ( P3N $_{3}$ ) Thin Films
}

\section{S. Eroglu}

TUBITAK-Marmara Research Center, Materials Research Division, P.K. 21, 41470 Gebze-Kocaeli, Turkey

\begin{abstract}
Thermodynamic analysis of the chemical vapor deposition (CVD) of $\mathrm{P}_{3} \mathrm{~N}_{5}$ has been performed using the method of the minimization of the Gibbs' free energy in order to evaluate the $\mathrm{PH}_{3}-\mathrm{NH}_{3}-\mathrm{N}_{2}, \mathrm{PCl}_{3}-\mathrm{NH}_{3}-\mathrm{H}_{2}$ and $\mathrm{PBr}_{3}-\mathrm{NH}_{3}-\mathrm{H}_{2}$ gaseous mixtures for their potential to synthesize single-phase $\mathrm{P}_{3} \mathrm{~N}_{5}$ films at high yields. The conditions for the deposition of $\mathrm{P}_{3} \mathrm{~N}_{5}$ have been determined as a function of input reactant gas ratio of $\mathrm{PX}_{3} /\left(\mathrm{PX}_{3}+\mathrm{NH}_{3}\right)(\mathrm{X}=\mathrm{H}$ or $\mathrm{Cl}$ or $\mathrm{Br})$ and deposition temperature at atmospheric pressure. A single phase $\mathrm{P}_{3} \mathrm{~N}_{5}$ is deposited at almost all reactant ratios and at temperatures below about $700 \mathrm{~K}$ when the $\mathrm{PH}_{3}-\mathrm{NH}_{3}-\mathrm{N}_{2}$ system is used. The use of halide gas mixtures limits the formation of single phase $\mathrm{P}_{3} \mathrm{~N}_{5}$ to narrow regions of temperature and input reactant gas ratio. The gaseous species generally present in greatest abundance are $\mathrm{H}_{2}, \mathrm{~N}_{2}, \mathrm{NH}_{3}$, $\mathrm{PH}_{3}, \mathrm{HCl}, \mathrm{P}_{4}, \mathrm{PCl}_{3}, \mathrm{P}_{2}, \mathrm{HBr}, \mathrm{PBr}_{3}$ and $\mathrm{PN}$. The thermodynamic analysis suggests that among the systems investigated here, the $\mathrm{PH}_{3}-\mathrm{NH}_{3}-\mathrm{N}_{2}$ mixture is the most promising because simultaneously it gives the highest $\mathrm{P}_{3} \mathrm{~N}_{5}$ deposition yield and allows better control of the CVD process for the synthesis of $\mathrm{P}_{3} \mathrm{~N}_{5}$ films.
\end{abstract}

\section{INTRODUCTION}

Phosphorus nitride $\left(\mathrm{P}_{3} \mathrm{~N}_{5}\right)$ thin films are receiving considerable attention as a gate insulator for InP metal-insulator-semiconductor (InP MIS) structures [1]. Studies [2-5] have mainly concentrated on the electrical characteristics of the InP MIS devices whose insulator films were prepared from the gaseous mixtures of $\mathrm{PH}_{3}-\mathrm{NH}_{3}-\mathrm{N}_{2}$ [2], $\mathrm{PCl}_{3}-\mathrm{NH}_{3}-\mathrm{H}_{2}$ [3,4] and $\mathrm{PH}_{3}-\mathrm{NF}_{3}-\mathrm{Ar}$ [5] by chemical vapor deposition (CVD) technique. There is a scarcity of published information on the chemical vapor deposition of $\mathrm{P}_{\mathbf{3}} \mathrm{N}_{\mathbf{5}}$ thin films. In order to understand the process and to optimize the film growth parameters such as temperature, initial gas composition and pressure, it seems essential to start with a thermodynamic investigation of the reactant systems used for the synthesis of $\mathrm{P}_{\mathbf{3}} \mathrm{N}_{\mathbf{5}}$ films. This study presents the results of thermodynamic calculations performed for the $\mathrm{PH}_{3}-\mathrm{NH}_{3}-\mathrm{N}_{2}, \mathrm{PCl}_{3}-\mathrm{NH}_{3}$ $\mathrm{N}_{2}$ and $\mathrm{PBr}_{3}-\mathrm{NH}_{3}-\mathrm{H}_{2}$ gas mixtures. The results were used to construct CVD phase diagrams which illustrate the influence of the most commonly used operating conditions of temperature and initial gas composition on the formation of stable phases. Equilibrium yields of $\mathrm{P}_{\mathbf{3}} \mathrm{N}_{\mathbf{5}}$ and gas phase composition were also determined as a function of temperature and input gas composition. Attempts were made to compare the results of the thermodynamic analysis with the experimental literature. 


\section{THERMODYNAMIC CALCULATIONS}

Thermodynamic calculations were conducted by the method of minimization of Gibbs' free energy [6] for the $\mathrm{PH}_{3}-\mathrm{NH}_{3}-\mathrm{N}_{2}, \mathrm{PCl}_{3}-\mathrm{NH}_{3}-\mathrm{H}_{2}$ and $\mathrm{PBr}_{3}-\mathrm{NH}_{3}-\mathrm{H}_{2}$ reactant gas mixtures. For a system of known initial gas compositions, the method computes both the vapor phase and film composition at a given temperature and pressure when equilibrium is reached. The calculations require specifying all possible species which can exist in the temperature range of interest. Gaseous species considered as constituents of the gas phase include $\mathrm{NH}_{2}, \mathrm{NH}_{3}, \mathrm{~N}_{2} \mathrm{H}_{4}, \mathrm{H}_{2}, \mathrm{~N}_{2}, \mathrm{PH}_{3}, \mathrm{PH}, \mathrm{PH}_{2}, \mathrm{P}$, $\mathrm{P}_{2}, \mathrm{P}_{4}, \mathrm{PN}, \mathrm{Cl}_{2}, \mathrm{HCl}, \mathrm{PCl}, \mathrm{PCl}_{3}, \mathrm{PCl}_{5}, \mathrm{Br}_{2}, \mathrm{HBr}, \mathrm{PBr}$ and $\mathrm{PBr}_{3} . \mathrm{P}_{3} \mathrm{~N}_{5}, \mathrm{P}$ (black), $\mathrm{P}$ (red,lv), $\mathrm{P}$ (red v), $\mathrm{P}$ (white), $\mathrm{P}$ ( $\mathrm{cr}, 1), \mathrm{NH}_{4} \mathrm{Cl}$ and $\mathrm{NH}_{4} \mathrm{Br}$ are the possible condensed equilibrium phases. The Gibbs' free energy of formation data for the species were taken from the JANAF tables [7]. The nature of the equilibrium phases and the partial pressures of the resulting gaseous species were determined at atmospheric pressure as a function of temperature in the range 500-800 $\mathrm{K}$ and input reactant gas ratio of $\mathrm{PX}_{3} /\left(\mathrm{PX}_{3}+\mathrm{NH}_{3}\right)$ (where $\mathrm{X}$ is $\mathrm{H}$ or $\mathrm{Cl}$ or $\mathrm{Br}$ ). The $\mathrm{PX}_{3} /\left(\mathrm{PX}_{3}+\mathrm{NH}_{3}\right)$ ratio ( $\beta$ ) was varied from zero to unity. $150 \mathrm{~mol}$ of $\left(\mathrm{PX}_{3}+\mathrm{NH}_{3}\right)$ and $300 \mathrm{~mol}$ of $\mathrm{N}_{2}$ or $\mathrm{H}_{2}$ were used in the calculations. Equilibrium yield of $\mathrm{P}_{3} \mathrm{~N}_{5}\left(\mathrm{n}_{(}\left(\mathrm{P}_{3} \mathrm{~N}_{5}\right)\right)$ was also calculated as a function of temperature and the input reactant gas ratio $(\beta)$ with respect to $\mathrm{PX}_{\mathbf{3}}$ according to the following equation:

$$
\mathrm{n}\left(\mathrm{P}_{3} \mathrm{~N}_{5}\right)=3 \mathrm{x} \frac{\mathrm{n}_{\text {eq. }}\left(\mathrm{P}_{\mathbf{3}} \mathrm{N}_{5}\right)}{\mathrm{n}\left(\mathrm{PX}_{3}\right)} \times 100
$$

where $\mathrm{n}_{\text {eq. }}\left(\mathrm{P}_{3} \mathrm{~N}_{5}\right)$ and $\mathrm{n}^{\circ}\left(\mathrm{PX}_{3}\right)$ are the number of mol of condensed $\mathrm{P}_{3} \mathrm{~N}_{5}$ phase in equilibrium state and the initial number of mol of gaseous $\mathrm{PX}_{3}$, respectively.

\section{RESULTS AND DISCUSSION}

\subsection{CVD Phase Diagrams}

Figures 1 (a)-(c) show CVD phase diagrams which depict stable phases as a function of deposition temperature and initial reactant gas ratio $(\beta)$. The $\mathrm{PH}_{3}-\mathrm{NH}_{3}-\mathrm{N}_{2}$ reactant gas mixtures exhibit a CVD diagram that consists of no condensed phase and a solid $\mathbf{P}_{3} \mathbf{N}_{5}$ phase fields as seen in the Fig. 1 (a). The $P_{3} N_{5}$ phase is stable for all reactant ratios at temperatures below about $700 \mathrm{~K}$. The borderline between the single-phase and no condensed phase fields sligthly shifts towards higher temperatures with increasing reactant ratio. Above $700 \mathrm{~K}$, there is no condensed phase, but only gas phase exists. Contrary to the $\mathrm{PH}_{3}-\mathrm{NH}_{3}-\mathrm{N}_{2}$ system, the halide gas mixtures lead to more complicated CVD phase diagrams which consist of various phase fields. Figure 1 (b) shows the CVD phase diagram for the $\mathrm{PCl}_{3}-\mathrm{NH}_{3}-\mathrm{H}_{2}$ reactant system dominated by no condensed phase, a single-phase $P_{3} N_{5}$ and two-phase $P_{3} N_{5}+P(r e d, v)$ fields. No condensed phase is obtained at temperatures above $640 \mathrm{~K}$. The $\mathrm{P}_{3} \mathrm{~N}_{5}$ phase field for the chloride system is located in the temperature range about $540-640 \mathrm{~K}$ below a reactant ratio of 0.4 . Above 0.4 , the single-phase $\mathrm{P}_{3} \mathrm{~N}_{5}$ field becomes narrower as the ratio increases and finally disappears at about 0.85 at which elemental $\mathrm{P}$ starts to form. The two-phase $\mathrm{P}_{3} \mathrm{~N}_{5}+\mathrm{P}$ field is confined to the temperatures of 520-610 $\mathrm{K}$ and to the reactant ratios of 0.4-1. The single-phase $\mathrm{P}$ field is widest at about $600 \mathrm{~K}$ and at the reactant ratios between 0.85 and 1 . At temperatures near $500 \mathrm{~K}$, solid $\mathrm{NH}_{4} \mathrm{Cl}$ is stable and the $\mathrm{P}_{3} \mathrm{~N}_{5}+\mathrm{NH}_{4} \mathrm{Cl}, \mathrm{P}_{3} \mathrm{~N}_{5}+\mathrm{P}+\mathrm{NH}_{4} \mathrm{Cl}$ and $\mathrm{P}+\mathrm{NH}_{4} \mathrm{Cl}$ phase fields appear as the input reactant ratio increases. A narrow strip of the $\mathrm{P}_{3} \mathrm{~N}_{5}+\mathrm{P}+\mathrm{NH}_{4} \mathrm{Cl}$ field (field I in the diagram) extends from 0.2 to about 1 at temperatures below $520 \mathrm{~K}$. Below this phase field, free $\mathrm{P}$ coexists with $\mathrm{NH}_{4} \mathrm{Cl}$ (phase field II). CVD phase diagram for the bromide system exhibits similar characteristics to that of the chloride system. The $\mathrm{P}_{3} \mathrm{~N}_{5}$ phase field is, however, narrower and located to be at temperatures between 575 and $640 \mathrm{~K}$ because the $\mathrm{NH}_{4} \mathrm{Br}$ formation starts at higher temperature of $575 \mathrm{~K}$. 

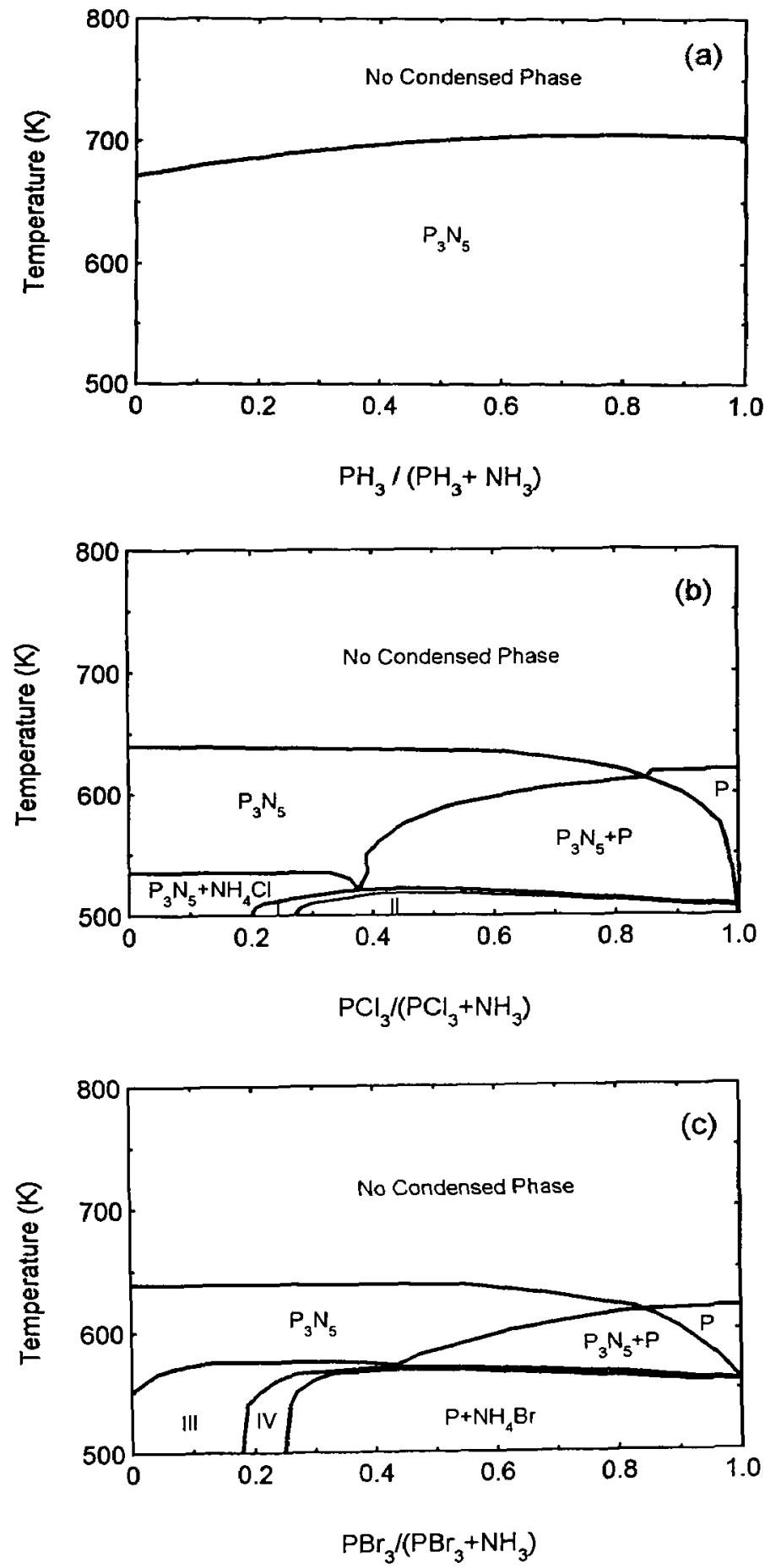

Figure 1: CVD phase diagrams showing the phases which are expected to form at equilibrium as a function of temperature and input gas ratios of (a) $\mathrm{PH}_{3} /\left(\mathrm{PH}_{3}+\mathrm{NH}_{3}\right)$, (b) $\mathrm{PCl}_{3} /\left(\mathrm{PCl}_{3}+\mathrm{NH}_{3}\right)$ and (c) $\mathrm{PBr}_{3} /\left(\mathrm{PBr}_{3}+\mathrm{NH}_{3}\right)$ at atmospheric pressure. I, II, III and IV represeni $\mathrm{P}_{3} \mathrm{~N}_{5}+\mathrm{P}+\mathrm{NH}_{4} \mathrm{Cl}, \mathrm{P}+\mathrm{NH}_{4} \mathrm{Cl}, \mathrm{P}_{3} \mathrm{~N}_{5}+\mathrm{NH}_{4} \mathrm{Br}, \mathrm{P}_{3} \mathrm{~N}_{5}+\mathrm{P}+\mathrm{NH}_{4} \mathrm{Br}$ phase fields, respectively. 


\subsection{Equilibrium Gas Phase Composition}

\subsubsection{Effect of Temperature}

Equilibrium concentrations of the gaseous species were calculated for temperatures between 500 and $800 \mathrm{~K}$ at a constant reactant ratio $\beta$ of 0.5 . The concentrations expressed in terms of partial pressures were a part of the same output from calculations which produced the CVD phase diagrams. The results are summarized in Figure 2 which illustrates the variation of the partial pressures of the species with temperature. Species with partial pressures smaller than $10^{-7}$ atm. were not included in the figures. Under equilibrium conditions, the concentration profiles represent the gas phase chemistry expected at the temperature range of interest. Figures 2 (a) and (b) show the gas phase composition for the $\mathrm{PH}_{3}-\mathrm{NH}_{3}-\mathrm{N}_{2}$ and $\mathrm{PCl}_{3}-\mathrm{NH}_{3}-\mathrm{H}_{2}$ systems, respectively. The results for the $\mathrm{PBr}_{3}-\mathrm{NH}_{3}-\mathrm{H}_{2}$ mixture are not presented because the calculations showed that both halide systems are analogous with respect to equilibrium gas phase composition.

As seen from Fig. 2(a), the gas phase in the $\mathrm{PH}_{3}-\mathrm{NH}_{3}-\mathrm{N}_{2}$ system consists of $\mathrm{N}_{2}, \mathrm{H}_{2}, \mathrm{NH}_{3}, \mathrm{P}_{4}$ $\mathrm{PH}_{3}, \mathrm{PN}$ and $\mathrm{P}_{2}$. Among these species, the partial pressures of $\mathrm{N}_{2}$ and $\mathrm{H}_{2}$ are calculated to be high and they are not affected by temperature. Strong influence of the temperature is seen for the other gaseous species. The partial pressure of $\mathrm{NH}_{3}$ decreases as the temperature increases. One of the dominant feature of the figure is that no P-containing species exist in the gas phase at lower temperatures. The $\mathrm{P}$-bearing $\mathrm{P}_{4}, \mathrm{PH}_{3}, \mathrm{PN}$ and $\mathrm{P}_{2}$ species are seen at higher temperatures and their partial pressures increase with temperature. Especially, there is a marked increase in the concentration of gaseous $\mathrm{P}_{4}$ species. The $\mathrm{P}_{4}$ partial pressure is constant at temperatures above 700 $\mathrm{K}$. It is also seen from the profiles that the partial pressures of $\mathrm{NH}_{3}$ and $\mathrm{PH}_{3}$ are smaller than their input values. Also notice that the partial pressure of $\mathrm{H}_{2}$ is very high. High $\mathrm{H}_{2}$ concentration is attributed to the decomposition of $\mathrm{NH}_{3}$ and $\mathrm{PH}_{3}$. At lower temperatures, no $\mathrm{P}$-bearing species are present in the gas phase because almost all $\mathrm{PH}_{3}$ is converted to solid $\mathrm{P}_{\mathbf{3}} \mathrm{N}_{\mathbf{5}}$ which is stable at temperatures lower than $700 \mathrm{~K}$. The partial pressure profiles in Fig. 2(a) indicate that the main equilibrium in the $\mathrm{PH}_{3}-\mathrm{NH}_{3}-\mathrm{N}_{2}$ system may be represented by the following reactions:

$$
\begin{aligned}
& 3 \mathrm{PH}_{3}+5 \mathrm{NH}_{3} \longrightarrow \mathrm{PH}_{3} \longrightarrow \mathrm{P}_{3} \mathrm{~N}_{5} \text { (solid) }+12 \mathrm{H}_{2} \\
& 4 \mathrm{PH}_{4}+6 \mathrm{H}_{2}
\end{aligned}
$$

Figure 2(b) illustrates the variation of the partial pressures of gaseous species for the $\mathrm{PCl}_{3}-\mathrm{NH}_{3}$ $\mathrm{H}_{2}$ system with the temperature. $\mathrm{H}_{2}$ and $\mathrm{HCl}$ species are seen to be the major species at all temperatures. With increasing temperature, the partial pressures of $\mathrm{N}_{2}$ and $\mathrm{P}_{4}$ reach significant levels. At lower temperatures, the concentrations of the P-bearing species of $\mathrm{P}_{4}, \mathrm{PH}_{3}, \mathrm{PCl}_{3}, \mathrm{P}_{2}$ and $P N$ are small. As the temperature increases, the partial pressures of $P_{4}, P_{2}$ and $P N$ species increase. Whereas those of $\mathrm{PH}_{3}$ and input reactant $\mathrm{PCl}_{3}$ decrease slightly with increasing temperature. It should be noted that the $\mathrm{P}_{4}$ gas is the major $\mathrm{P}$-bearing species at all temperatures investigated. It is seen that the partial pressure of $\mathrm{P}_{4}$ increases with temperature and above 640 $\mathrm{K}$ remains constant. The partial pressure profiles indicate that the concentrations of input $\mathrm{PCl}_{3}$ and $\mathrm{NH}_{3}$ gaseous species are relatively low while the products $\mathrm{HCl}, \mathrm{P}_{4}$ and $\mathrm{N}_{2}$ have high concentrations. The profiles suggest that solid $\mathrm{P}_{3} \mathrm{~N}_{5}$, gaseous $\mathrm{HCl}$ and $\mathrm{P}_{4}$ species may be formed by the following reactions:

$$
\begin{aligned}
& 3 \mathrm{PCl}_{3}+5 \mathrm{NH}_{3} \longrightarrow \mathrm{P}_{3} \mathrm{~N}_{5} \text { (solid) }+9 \mathrm{HCl}+3 \mathrm{H}_{2} \\
& 4 \mathrm{PCl}_{3}+6 \mathrm{H}_{2} \longrightarrow \mathrm{P}_{4}+12 \mathrm{HCl}
\end{aligned}
$$

Eqns. (4) and (5) can also be assumed for the $\mathrm{PBr}_{3}-\mathrm{NH}_{3}-\mathrm{H}_{2}$ mixtures because both halide systems are analogous with respect to CVD diagrams and gas phase composition. 


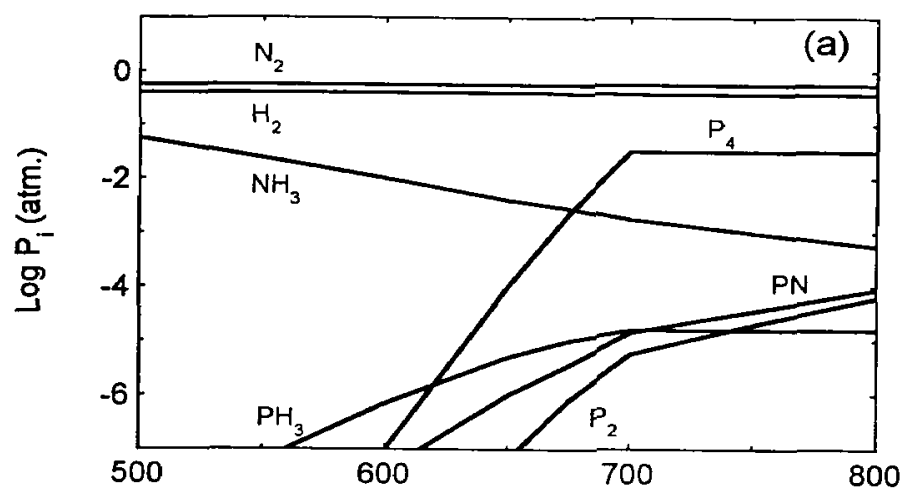

Temperature $(\mathrm{K})$

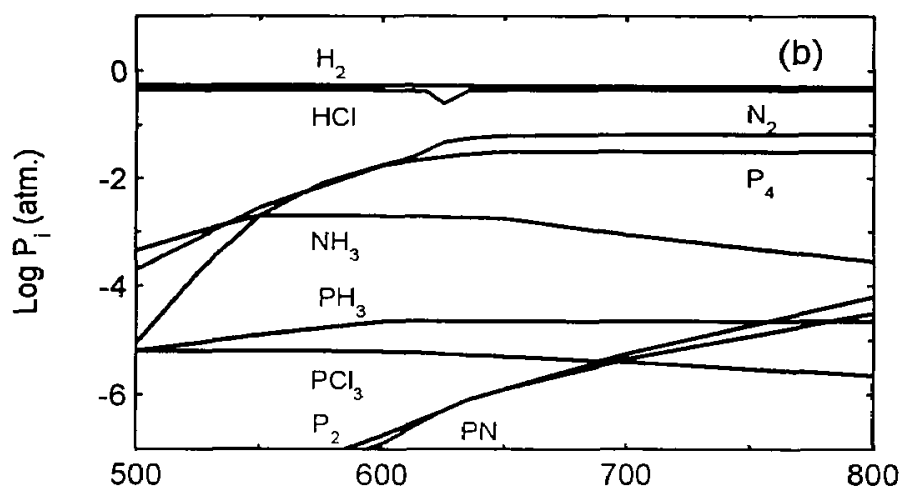

Temperature $(K)$

Figure 2: Variation of the partial pressure of the gaseous species with temperature at a $\mathrm{PX}_{3} /\left(\mathrm{PX}_{3}+\mathrm{NH}_{3}\right)$ ratio of 0.5 for (a) $\mathrm{PH}_{3}-\mathrm{NH}_{3}-\mathrm{N}_{2}$ and (b) $\mathrm{PCl}_{3}-\mathrm{NH}_{3}-\mathrm{H}_{2}$ gas mixtures, where $\mathrm{X}$ is $\mathrm{H}$ or $\mathrm{Cl}$.

\subsubsection{Effect of Reactant Ratio}

The effect of input reactant ratio $(\beta)$ on the gas phase composition is studied at a temperature of $600 \mathrm{~K}$. The results are summarized in Figures $3(\mathrm{a})$ and (b) for the $\mathrm{PH}_{3}-\mathrm{NH}_{3}-\mathrm{N}_{2}$ and $\mathrm{PCl}_{3}-\mathrm{NH}_{3}-\mathrm{H}_{2}$ systems, respectively. The major species in the $\mathrm{PH}_{3}-\mathrm{NH}_{3}-\mathrm{N}_{2}$ reactant mixtures are obtained to be $\mathrm{N}_{2}$ and $\mathrm{H}_{2}$. The species of $\mathrm{PH}_{3}, \mathrm{P}_{4}$ and $\mathrm{NH}_{3}$ have lower partial pressures than those of $\mathrm{N}_{2}$ and $\mathrm{H}_{2}$. Low $\mathrm{PH}_{3}$ concentrations suggest that almost all $\mathrm{PH}_{3}$ species is used for $\mathrm{P}_{3} \mathrm{~N}_{5}$ deposition. $\mathrm{P}_{4}$ species starts to form at an input reactant ratio of 0.7 . The dominant feature in these profiles is that the concentration of the species are not influenced by the input reactant ratio. In the halide reactant gas systems, strong dependence of the gas phase composition on the input reactant ratio is obtained as shown in Figure 3(b) for the $\mathrm{PCl}_{3}-\mathrm{NH}_{3}-\mathrm{H}_{2}$ system. Major gaseous species at lower reactant ratios are seen to be $\mathrm{H}_{2}, \mathrm{HCl}, \mathrm{N}_{2}$ and $\mathrm{NH}_{3}$. P-bearing species of $\mathrm{P}_{4}, \mathrm{PH}_{3}$ and $\mathrm{PCl}_{3}$ have low partial pressures at low reactant ratios as expected. The concentrations of these species increase with increasing reactant ratio. The partial pressure of the major P-containing species of $\mathrm{P}_{4}$ reaches significant levels close to that of $\mathrm{N}_{2}$. $\mathrm{HCl}$ species is present in high quantities which increase with the reactant ratio. The amount of the unreacted $\mathrm{PCl}_{3}$ is small at low reactant ratios, but it increases with the input reactant gas ratio. Eqns. (2), (4) and (5) can also be considered as the main equilibrium reactions to produce $P_{3} N_{5}$ and other species. 

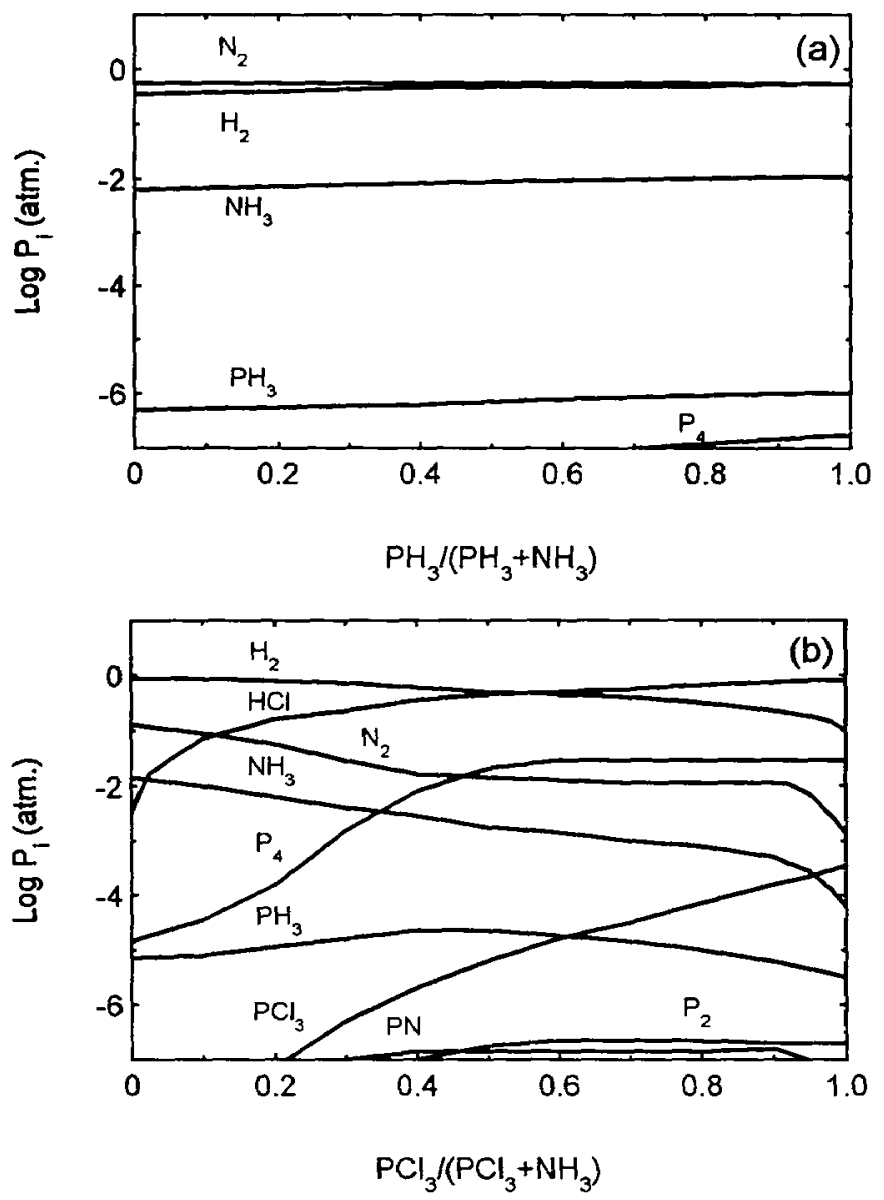

Figure 3: Variation of the partial pressure of the gaseous species with (a) $\mathrm{PH}_{3} /\left(\mathrm{PH}_{3}+\mathrm{NH}_{3}\right.$ ) and (b) $\mathrm{PCl}_{3} /\left(\mathrm{PCl}_{3}+\mathrm{NH}_{3}\right)$ ratios at $600 \mathrm{~K}$

\subsection{Equilibrium Yields}

Figures 4(a) and (b) show the variations of equilibrium yield of $\mathrm{P}_{3} \mathrm{~N}_{5}$ with temperature at a reactant ratio $(\beta)$ of 0.5 and with the reactant ratio $(\beta)$ at $600 \mathrm{~K}$, respectively. It is seen from Figure 4(a), the $\mathrm{P}_{3} \mathrm{~N}_{5}$ yield of $100 \%$ is obtained at temperatures lower than $700 \mathrm{~K}$ when the $\mathrm{PH}_{3}-\mathrm{NH}_{3}-\mathrm{H}_{2}$ is employed. The yield sligthly decreases as the temperature approaches $700 \mathrm{~K}$. It becomes zero at $700 \mathrm{~K}$ above which no condensed phase exists as the CVD diagram indicated. For the chloride and bromide reactant mixtures, $\mathrm{P}_{3} \mathrm{~N}_{5}$ yields are obtained to be highest about $50 \%$ at temperatures 520 and $580 \mathrm{~K}$, respectively. Above these temperatures, the decline in $\mathrm{P}_{3} \mathrm{~N}_{5}$ yield is observed because increasingly some of $\mathrm{PCl}_{3}$ or $\mathrm{PBr}_{3}$ gaseous species is converted to gaseous $\mathrm{P}_{4}$. The yield is zero at $640 \mathrm{~K}$ above which solid $\mathrm{P}_{3} \mathrm{~N}_{5}$ phase is not stable.

The effect of the reactant gas ratio on the $\mathrm{P}_{3} \mathrm{~N}_{5}$ yield at $600 \mathrm{~K}$ is shown in Figure $4(\mathrm{~b})$. For the $\mathrm{PH}_{3}-\mathrm{NH}_{3}-\mathrm{N}_{2}$ system, the $\mathrm{P}_{3} \mathrm{~N}_{5}$ yield is calculated to be $100 \%$ at all reactant ratios. This is not surprising because the partial pressure profiles showed that the concentration of the P-bearing species are very small, indicating that all $\mathrm{P}$-containing species are converted to solid $\mathrm{P}_{3} \mathrm{~N}_{5}$. For the halide gas mixtures, a high $\mathrm{P}_{3} \mathrm{~N}_{5}$ yield of $\% 100$ is obtained at reactant ratios in the range $0-0.2$ Above the ratio of 0.2 , the yield decreases with increasing reactant ratio up to 0.9 at which the yield becomes zero. This behavior is attributable to gaseous $\mathrm{P}_{4}$ species whose concentration increases with the reactant ratio and to the elemental solid $\mathrm{P}$ formation. 


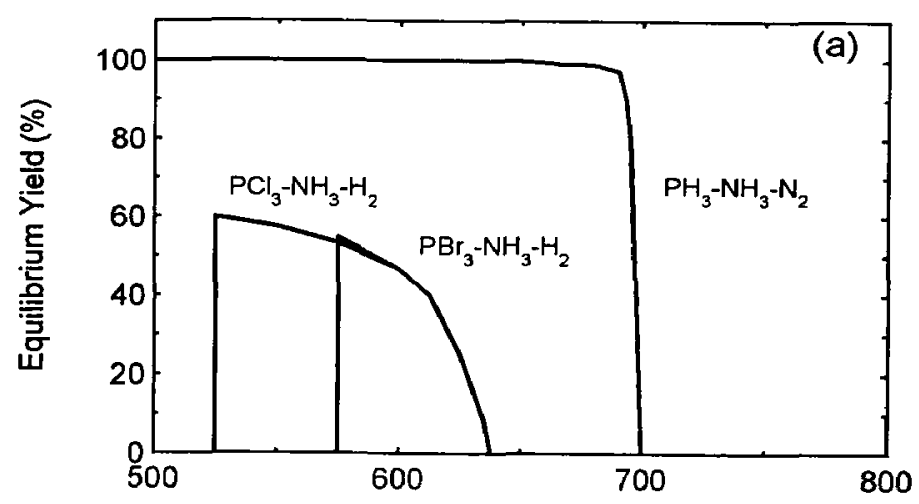

Temperature (K)

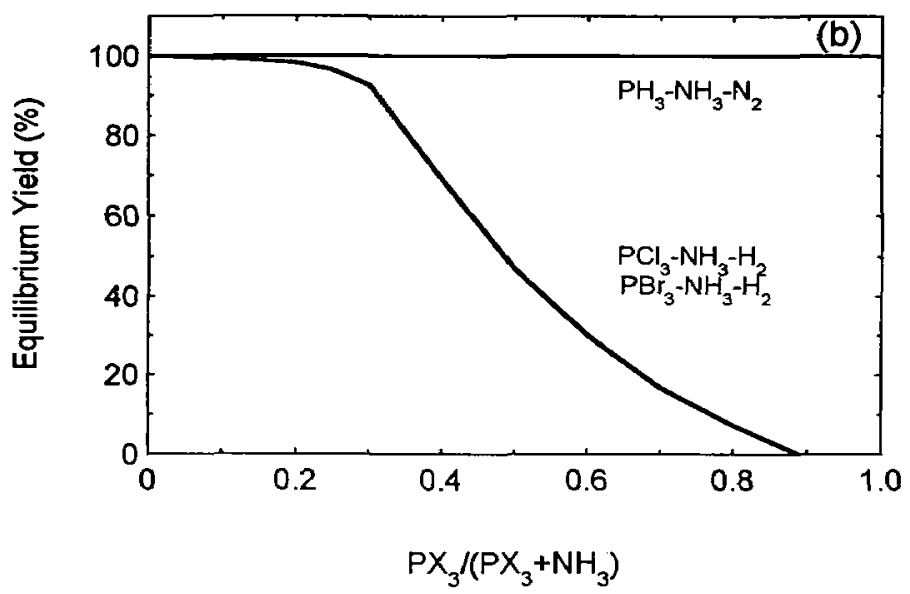

Figure 4: Variation of $\mathrm{P}_{3} \mathrm{~N}_{5}$ equilibrium yields with (a) temperature at a constant $\mathrm{PX}_{3} /\left(\mathrm{PX}_{3}+\mathrm{NH}_{3}\right)$ reactant ratio of 0.5 and with (b) $\mathrm{PX}_{3} /\left(\mathrm{PX}_{3}+\mathrm{NH}_{3}\right)$ reactant ratio at $600 \mathrm{~K}$, where $\mathrm{X}$ is $\mathrm{H}$ or $\mathrm{Cl}$ or $\mathrm{Br}$.

\subsection{Comparison With Experimental Literature}

It was intended to make a detailed comparison of the present calculated results with the experimental data reported in the literature. Two major problems were, however, encountered. First, the range of the conditions covered for a particular reactant system has been generally small. Second, all the necessary experimental conditions have not been clearly reported. Typically, carrier gas concentrations are omitted. Jeong et al. [3] reported that the $\mathbf{P}_{\mathbf{3}} \mathrm{N}_{5}$ deposition from the $\mathbf{P C l}_{3}$ $\mathrm{NH}_{3}-\mathrm{H}_{2}$ reactant mixtures occurs at temperatures above $525 \mathrm{~K}$. Iwase et al. [4] deposited $\mathrm{P}_{3} \mathrm{~N}_{5}$ films from the $\mathrm{PCl}_{3}-\mathrm{NH}_{3}-\mathrm{H}_{2}$ gaseous mixtures at temperatures between 525 and $775 \mathrm{~K}$ and at low reactant ratios of $\mathrm{PCl}_{3}$ to $\mathrm{NH}_{3}$. These experimental conditions reported for the deposition of $\mathrm{P}_{3} \mathrm{~N}_{5}$ thin films in the $\mathrm{PCl}_{3}-\mathrm{NH}_{3}-\mathrm{H}_{2}$ system are found to be in fairly good agreement with the thermodynamic predictions, which indicated that the high yield $\mathrm{P}_{\mathbf{3}} \mathrm{N}_{\mathbf{5}}$ deposition should take place at temperatures between 540 and $640 \mathrm{~K}$ and at low reactant ratios.

No studies on the chemical vapor deposition of $\mathrm{P}_{3} \mathrm{~N}_{5}$ films from the $\mathrm{PBr}_{3}-\mathrm{NH}_{3}-\mathrm{H}_{2}$ reactant mixtures have been reported in the literature.

For the $\mathrm{PH}_{3}-\mathrm{NH}_{3}-\mathrm{H}_{2}$ reactant system, a $\mathrm{P}_{3} \mathrm{~N}_{5}$ deposition temperature of $900 \mathrm{~K}$ is reported [2] and this temperature is found to be higher than $700 \mathrm{~K}$, which is the upper limit of $\mathbf{P}_{3} \mathrm{~N}_{5}$ deposition temperature as predicted by thermodynamic calculations. Poor agreement between the 
experimental results and equilibrium calculations suggests that kinetic factors such as the relative disassociation rates of the gaseous species and mass transport effects may be controlling the deposition process.

\section{CONCLUSIONS}

Thermodynamic analysis of the potential routes for the chemical vapor deposition of $\mathrm{P}_{\mathbf{3}} \mathrm{N}_{\mathbf{5}}$ thin films was presented as a function of CVD parameters of temperature and reactant gas ratio. CVD phase diagrams in the $\mathrm{PH}_{3}-\mathrm{NH}_{3}-\mathrm{N}_{2}$ system indicated that a single $\mathrm{P}_{3} \mathrm{~N}_{5}$ phase is deposited for all reactant ratios at temperatures below $700 \mathrm{~K}$, above which no condensed phase exists. The deposition range of the single phase $\mathrm{P}_{3} \mathrm{~N}_{5}$ is limited to temperatures between 540 and $640 \mathrm{~K}$ at reactant ratios below 0.85 when the $\mathrm{PCl}_{3}-\mathrm{NH}_{3}-\mathrm{H}_{2}$ system is employed. In the $\mathrm{PBr}_{3}-\mathrm{NH}_{3}-\mathrm{H}_{2}$ system, the CVD diagram is shown to be similar to that of the $\mathrm{PCl}_{3}-\mathrm{NH}_{3}-\mathrm{H}_{2}$ mixtures. The partial pressure profiles of the gaseous species showed that the species present in the gas phase are $\mathrm{N}_{2}, \mathrm{H}_{2}, \mathrm{NH}_{3}, \mathrm{PH}_{3}, \mathrm{P}_{4}, \mathrm{PN}$, $\mathrm{P}_{\mathbf{2}}, \mathrm{HCl}$ and $\mathrm{PCl}_{3} . \mathrm{P}_{4}$ was found to be major $\mathrm{P}$-bearing species whose partial pressure increases with temperature and reactant ratio, causing $\mathrm{P}_{\mathbf{3}} \mathrm{N}_{\mathbf{5}}$ yield to decline. The profiles were used to elucidate the paths to the formation of $\mathrm{P}_{3} \mathrm{~N}_{5}$ and gaseous species such as $\mathrm{HCl}, \mathrm{P}_{4}$. Good agreement between the experimental literature and the thermodynamic calculations was found for the system of $\mathrm{PCl}_{3}-\mathrm{NH}_{3}-\mathrm{H}_{2}$. Thermodynamic analysis suggests that the $\mathrm{PH}_{3}-\mathrm{NH}_{3}-\mathrm{N}_{2}$ system has advantages over the halide mixtures because simultaneously it gives the highest yield and allows better control of the CVD process for the synthesis of a single phase $\mathrm{P}_{\mathbf{3}} \mathrm{N}_{\mathbf{5}}$ thin films. However, kinetic effects and mass transport effects should also be considered.

\section{References}

[1] Jeong Y.H., Kim G.T., Kim S.T., Kim K.I. and Chung W.J., J.Appl.Phys. 69 (1991) 6699-6700.

[2] Hirota Y. and Kobayashi T., J.Appl.Phys. 53 (1982) 5037-5043.

[3] Jeong Y.H., Takagi S., Arai F. and Sugano T., J.Appl.Phys. 62 (1987) 2370-2375.

[4] Iwase Y., Arai F. and Sogano T., Appl.Phys.Lett. 52 (1988) 1437-1438.

[5] Furukawa Y., Jpn.J.Appl.Phys. 23 (1984) 376-377.

[6] Besmann T.M., "SOLGASMIX-PV, A Computer Program to Calculate Equilibrium Relationships in Complex Chemical Systems", Oak Ridge National Laboratory Report No.ORNL/TM-5775, (Oak Ridge, TN, 1977).

[7] Chase M.W., Davies C.A., Downey J.R., Frurip D.J., McDonald R.A. and Syverud A.N., JANAF Thermochemical Tables, J. Phys. Chem. Ref. Data Suppl. 14 (1985). 